\title{
National nostalgia: A group-based emotion that benefits the in-group but hampers intergroup relations
}

\author{
Anouk Smeekes* \\ ERCOMER, Utrecht University, Padualaan 14, P.O. Box 80140, 3508 TC Utrecht, The Netherlands
}

\section{A R T I C L E I N F O}

\section{Article history:}

Received 10 February 2015

Received in revised form 24 June 2015

Accepted 6 July 2015

\section{Keywords:}

Group-based nostalgia

National identity

Prejudice

Ethnic

Essentialism

Continuity

\begin{abstract}
A B S T R A C T
Social psychological research on nostalgia has mainly considered this emotion at the individual level rather than the group level. The current paper proposes that group-based nostalgia for the nation (i.e., national nostalgia) is likely to be related to a positive in-group orientation and a negative out-group orientation, because it fosters an exclusionary and essentialist sense of national identity that is based on ancestry and common descent (i.e., ethnic national identity). This prediction was tested in three survey studies. Study 1 was conducted among a broad sample of the native Dutch population, and demonstrated that national (and not personal) nostalgia is positively related to national in-group identification and out-group prejudice. Study 2 replicated the findings of Study 1 among a nationally representative sample of the native Dutch population, and provided support for the mediation by ethnic national identity. Study 3 replicated the findings of Study 2 and additionally demonstrated that national nostalgia positively predicts tendencies to protect national ingroup identity, via a stronger sense of ethnic national identity. These findings demonstrate the potential of group-based nostalgia to have positive and negative consequences for group dynamics at the same time.
\end{abstract}

(c) 2015 Elsevier Ltd. All rights reserved.

\section{Introduction}

In various Western European countries, public debates on immigration and cultural diversity have become increasingly nostalgic. Both right and left wing politicians have claimed that, as a consequence of the growing cultural and religious diversification of Western European societies, native majority members no longer feel at home in their country and neighborhoods and increasingly long for the good old days of when it was "just us" (Duyvendak, 2011). Scholars suggest that group-based nostalgia for the nation emerges in times of social change and transformation, and makes nationals more aware of the values and symbols that bind them as a national community (e.g., Boym, 2001; Hewison, 1987). However, as longing for the national past makes clear what constitutes a country's unique cultural heritage, it also emphasizes how "we" are different from other groups. This means that while national nostalgia is likely to provide a sense of attachment to fellow national in-group members, it may mark group boundaries and hamper positive intergroup relations.

The current research examines the consequences of group-based nostalgia for the nation (i.e., national nostalgia) for group dynamics. Specifically, it is proposed that national nostalgia is likely to have positive consequences for the national in-group but negative consequences for the evaluation of immigrant out-groups. In social psychology, most work on nostalgia has

\footnotetext{
* Fax: +31 302534733.

E-mail address: A.N.Smeekes@uu.nl
} 
focused on the individual level of analysis. That is, studies have looked at nostalgia that is experienced for things related to one's individual biography (i.e., personal nostalgia) and how this affects individual-level outcomes, such as self-esteem (Hepper, Ritchie, Sedikides, \& Wildschut, 2012) and social connectedness (Wildschut, Sedikides, Arndt, \& Routledge, 2006). Recently, research by Wildschut, Bruder, Robertson, Tilburg, and Sedikides (2014) has introduced nostalgia as a group-level emotion (i.e., group-based nostalgia), and demonstrated that it has positive consequences for the in-group. Furthermore, other recent work by Smeekes, Verkuyten, and Martinovic (2014) has shown that national nostalgia has negative consequences for natives' acceptance of expressive rights for Muslim immigrants. The current research extends this work by examining how national nostalgia differentially affects in-group attachment and out-group prejudice, and whether these relationships can be explained by the endorsement of an exclusionary group identity representation.

\subsection{Group-based nostalgia: a bittersweet group-level emotion}

The nature of nostalgia (from the Greek words nostos - return home, and algia - longing/suffering) has been the subject of much debate. While some scholars describe nostalgia as a predominantly negative emotion, characterized by feelings of loss and mourning for a past that no longer exists (e.g., Best \& Nelson, 1985; Holbrook, 1993), others view it as primarily positive, typically involving happy memories of the past (Batcho, 1998; Davis, 1979; Sedikides, Wildschut, \& Baden, 2004). Still others, including Frijda (2007), have described nostalgia as an ambivalent emotion, involving both positive and negative affect. According to Frijda (2007, pp. 87-88), nostalgia is: "a true bittersweet emotion: pain because of pleasures past, or pleasure because of pleasures that have gone. The pleasure is not full; the pain not pungent". Research in social psychology confirms this ambivalent nature of nostalgia, by showing that, for lay persons, nostalgia most often involves fond memories of a certain time or person(s), for which they long or which they miss (Hepper et al., 2012). Although these and other findings (Wildschut et al., 2006) support the notion that nostalgia is affectively mixed, most research in social psychology has emphasized the positive aspects and consequences of nostalgia (for an overview see Batcho, 2013).

However, during the last few years studies have emerged showing that nostalgia may not always have positive implications for individual well-being. For instance, research in the context of life transitions, found that nostalgia had positive consequences to deal with present challenges when identity continuity was high, but had negative consequences for individual functioning when identity continuity was low (Iyer \& Jetten, 2011). These scholars propose that when individuals feel that they are no longer connected to who they were in the past, a nostalgic longing for this past mainly serves as a painful reminder of the good things that are left behind, which hampers individual's capacity to move on and face current challenges. Yet, like most research in social psychology, this study focused on personal nostalgia and studied its consequences for individual level outcomes. More recently, studies emerged that studied the consequences of nostalgia for intergroup relations (Turner, Wildschut, \& Sedikides, 2012; Turner, Wildschut, Sedikides, \& Gheorghiu, 2013). These studies showed that nostalgia for an encounter with an out-group member improved attitudes towards this out-group. However, these studies focused on interpersonal nostalgia and did not look at the feelings of nostalgia that people may experience in relation to their in-group membership.

As people derive part of their sense of self from their memberships in groups (Tajfel \& Turner, 1979), they can also experience emotions on behalf of their group membership. While there is an extensive body of research in social psychology on group-based emotions, such as guilt (e.g., Branscombe \& Doosje, 2004), group-based nostalgia has been introduced in the field only recently (see Smeekes et al., 2014; Wildschut et al., 2014). Following the criteria for identifying a group-level emotion as postulated by intergroup emotions theory (Mackie, Devos, \& Smith, 2000; Mackie \& Smith, 1998), Wildschut et al. (2014) showed that group-based nostalgia qualifies as a group-level emotion. Specifically, they found that group-based nostalgia can be differentiated from personal nostalgia and that it motivates and regulates positive attitudes and behaviors towards the in-group.

The current research builds on this line of work by examining how group-based nostalgia affects orientations towards the in-group as well as towards out-groups. Specifically, it focuses on group-based nostalgia for the nation(i.e., national nostalgia) among native majority members in the Netherlands. In line with earlier definitions of group-level emotions (Mackie et al., 2000) and group-based nostalgia (Wildschut et al., 2014), I define national nostalgia as the feelings of nostalgia that are experienced on the basis of one's national in-group membership. Specifically, I propose that in culturally diverse settings in Western Europe, the feeling of national nostalgia that is experienced by native majority members refers to a combined sense of loss and longing for their (fondly remembered) national homes of the past.

\subsection{Group-based nostalgia, social categorization and moral community}

Theoretical work on group-based nostalgia has proposed that it often emerges in times of social change and transition, because it serves to restore a sense of identity continuity (Boym, 2001; Davis, 1979; Hewison, 1987; Milligan, 2003). When the social environment changes, in-group members may get the feeling that they are losing their connection to "who we were" in the past, which results in a feeling of identity discontinuity. Social psychological research has shown that that identity discontinuity is associated with psychological discomfort and distress (e.g., Jetten, Haslam, Pugliese, Tonks, \& Haslam, 2010), and that it forms an important psychological basis for both individual and collective identities (Sani, 2008; Smeekes \& Verkuyten, 2013, 2014). It is suggested that group-based nostalgia can repair this sense of identity discontinuity by creating a shared social identity to mend the lost one (Hewison, 1987; Milligan, 2003). Specifically, group-based nostalgia is proposed 
to instill a renewed sense of social identity among individuals that is based on their awareness of shared past experiences (Davis, 1979).

Supporting this assertion, qualitative research among a group of employees has shown that they experienced discontinuity of their employee identity after moving to a new site, which resulted in a group-based nostalgia for their lost environment (Milligan, 2003). Subsequently, Milligan (2003) observed that a new employee identity emerged in relation to the old employee identity. Old employees felt that new employees typically did not hold the same values and attitudes, because they were not part of the old working environment. As a result, for old employees the new employees would never be "old", and new employees were also seen as less committed and loyal to the organization. Similarly, ethnographic work by Kasinitz and Hillyard (1995) described how group-based nostalgia emerged among working-class whites in an urban American neighborhood when it changed as a result of non-white newcomers. The group-based nostalgia they observed consisted of longings for the moral solidarity of the old ethnic neighborhood, which was characterized by closely knit family networks in which people cared for one another and typically held the same norms and values.

Taken together, these findings first suggest that group-based nostalgia is likely to result in processes of social categorization based on temporality-between the old "us" that share a past and the new "them" who are not part of this past. The reason is that the collective longing for a shared past that is lost makes a social category based on these collective experiences salient, which helps "old-timers" to regain a sense of identity continuity. This is in line with propositions from self-categorization theory (SCT; Turner, Hogg, Oakes, Reicher, \& Wetherell, 1987), suggesting that when a shared social identity is salient individuals tend to see and define themselves as interchangeable representatives of their shared social category membership (rather than as individual persons), and also tend to perceptually accentuate intragroup similarities and intergroup differences on relevant dimensions of social comparison.

Second, these findings indicate that group-based nostalgia encompasses more than mere categorization between oldtimers and newcomers. Namely, both Milligan (2003) and Kasinitz and Hillyard (1995) observed that old-timers typically felt that they had better values than newcomers and were also more loyal and committed to their community. This suggests that in longing for the positively viewed shared experiences of the past group members may also start to consider themselves part of a moral community for which they are responsible in terms of ensuring its continuity. That is, in these cases of groupbased nostalgia seems to lie a moral sentiment which idealizes the collective past as being one in which people still held "the right" norms and values. This idea is in line theoretical work by Turner (1987), suggesting that one of the dimensions of the social and cultural discourse of nostalgia is a sense of loss of moral certainty (p. 150). This refers to the idea that human history is perceived in terms of a collapse of values which provided social cohesion and unity in the good old days of the past. Psychologists have described a moral community as having "a set of shared norms about how members ought to behave, combined with means for imposing costs on violators and/or channeling benefits to cooperators" (Haidt, 2007, p. 1000; see also Opotow, Gerson, \& Woodside, 2010). That is, a moral community expresses group unity through a shared set of moral norms and values. This relates to propositions from SCT suggesting that the process of self-stereotyping in terms of a shared social identity also activates the in-group prototype-a representation of what defines the group as a whole (e.g., norms, values, and beliefs) and what characteristics define its members (Terry \& Hogg, 1996). This in-group prototype indicates the criteria for group membership and is used to include or exclude potential new members, but will vary as a function of the comparative context. That is, the in-group prototype depends on which out-group functions as the basis for social comparison in a given context (Reicher \& Hopkins, 2001).

Applying both SCT and the literature on moral communities to the context of native majority members facing increasing diversification of their surroundings, it can be expected that when they experience group-based nostalgia for their lost national home of the past this is likely to activate an in-group prototype of "old-timers" as being part of a moral community based on shared past experiences. In order to ensure a sense of identity continuity of this moral community, this in-group prototype clearly marks group boundaries between "us" - the old/original inhabitants of the country who share "the right" norms and values (i.e., native majority members) and "them" - those who have arrived later from elsewhere and who do not share these norms and values (i.e., immigrants).

\subsection{Ethnic national identity, essentialism and out-group prejudice}

One in-group prototype that could reflect this moral community is the representation of ethnic national identity (Pehrson, Brown, \& Zagefka, 2009; Smith, 2001), which portrays the national in-group as a community of people with common ancestry and descent. This representation excludes immigrants from national in-group membership as they do not fit the ancestry requirement. Within the understanding of ethnic national identity lies the idea that national group membership is based on immutable and fixed characteristics, indicating that it contains beliefs of essentialism. In social psychology, essentialism is understood as the belief in social categories as having an underlying core that is eternal and unchanging (Haslam, Bastian, Bain, \& Kashima, 2006; Haslam, Roschild, \& Ernst, 2000). This implies that, when social categories are essentialized, membership in a certain category is seen as fixed and impermeable, and therefore changeless. It has been shown that cultural essentialist understandings of national identity bolster national in-group identification, because they satisfy the need for identity continuity (Smeekes \& Verkuyten, 2014). Ethnic national identity ascribes essences to national group membership based on ancestry and common descent and can therefore be a source of cultural continuity. That is, by representing national identity as being ethnically rooted and fixed the native majority ensures the continuity of its cultural 
norms, values and traditions (i.e., moral community). As such, it is likely that national nostalgia among native majority members is positively related to an essentialist ethnic understanding of national identity.

Previous work in social psychology has established the positive influence of group-based nostalgia on in-group evaluations (Wildschut et al., 2014) and its negative influence on out-group attitudes (Smeekes et al., 2014). However, few studies have examined whether these relations can be simultaneously explained by processes of social categorization and in-group essentialism. According to SCT, the in-group prototype that is activated by social categorization also contains the norms for appropriate in-group behavior, and is therefore important in determining in-group and out-group attitudes. An ethnic national in-group prototype stands for exclusive norms and impermeable group boundaries, as those who do not share common heritage and ancestry can never become in-group members. Research has demonstrated that the endorsement of ethnic national identity among native majority members results in stronger national in-group identification (Duriez, Reijerse, Luyckx, Vanbeselaere, \& Meeus, 2013) and more prejudice towards immigrant out-groups (e.g., Kunovich, 2009; Pehrson et al., 2009; Wakefield et al., 2011). As such, it is hypothesized that national nostalgia among native majority members is positively related to national in-group identification and immigrant out-group prejudice, because it fosters an ethnic understanding of national identity.

\subsection{The present research}

This research examines group-based nostalgia in the context of the nation and investigates how it affects intragroup and intergroup dynamics. It looks at national nostalgia among native majority members in the Netherlands and predicted that national nostalgia is positively related to national in-group identification and out-group prejudice, via a stronger sense of ethnic national identity. In the Dutch context, this representation of ethnic national identity is widely used in public and political discourses as a boundary marker of national identity between natives and immigrants (see e.g., Duyvendak, 2011). The hypotheses were tested in three studies. Study 1 was a survey study among a broad sample of the native Dutch population and examined the relations between national nostalgia, in-group identification and out-group prejudice, while controlling for personal nostalgia. Study 2 examined these relationships among a nationally representative sample of the native Dutch population and furthermore tested the mediational role of ethnic national identity. Study 3 (also based on a nationally representative sample) examined the same predictions as Study 2, and additionally tested whether national nostalgia is related to a tendency to protect the future vitality of the national in-group, via a stronger sense of ethnic national identity.

\section{Study 1}

Study 1 was designed to test the hypothesis that national nostalgia is a unique and relevant predictor of national in-group identification and prejudice towards immigrant out-groups. Although research has shown that group-based nostalgia rather than personal nostalgia is related to positive in-group (Wildschut et al., 2014) and negative out-group evaluations (Smeekes et al., 2014) these findings were based on student samples and did not examine orientations towards the in-group and outgroup simultaneously. Furthermore, in social psychology major concerns have been raised about the wide use of student samples and the lack of replication of findings, and people have emphasized the importance of carrying out replication studies among broader samples that can test robustness as well as generalizability of the findings (Asendorpf et al., 2013; Henrich, Heine, \& Norenzayan, 2010; Henry, 2008; Simons, 2014). Therefore, next to the main hypotheses, Study 1 aimed to replicate the empirical distinctiveness and differential effects of personal and national nostalgia among a broader sample of native Dutch adults.

\subsection{Method}

\subsubsection{Participants}

This study ( $N=197)$ was conducted among a sample of the native Dutch population (36.5\% women) aged between 19 and 85 years $(M=51.83, \mathrm{SD}=14.91)$. Participants received a questionnaire by means of an e-mail sent by a survey company (Thesistools.be), and were drawn from a panel of native Dutch respondents maintained by this company.

\subsubsection{Measures}

2.1.2.1. Personal and national nostalgia. In order to measure personal and national nostalgia, participants rated on a 5-point scale $(1=$ not at all, $5=$ very $m u c h)$ the extent to which they longed for 6 specific aspects of their past. For personal nostalgia the items were: "My family house", "My childhood toys", and "My school" $(\alpha=.73)$. For national nostalgia the items were: "The way Dutch people were", "The way Dutch society was", and "The way the Dutch landscape (i.e., surroundings) looked like" $(\alpha=.88)$. These measures have been used in previous work (see Smeekes et al., 2014).

2.1.2.2. Out-group prejudice. Out-group prejudice was assessed with the well-known feeling thermometers. On a 11-point scale ranging from $0^{\circ}$ and $11^{\circ}$ to $100^{\circ}$ (with $10^{\circ}$ increments between two adjacent scale points), participants had to indicate how positive (i.e., warm) their feelings were towards each of the four largest non-Western immigrant groups in the 
Table 1

Fit indices of models tested in confirmatory factor analyses, Studies 1 and 2.

\begin{tabular}{|c|c|c|c|c|c|}
\hline & $\chi^{2}(\mathrm{df})$ & $\Delta \chi^{2}$ & CFI & TLI & RMSEA \\
\hline \multicolumn{6}{|l|}{ Study 1} \\
\hline 1) 4-factors & $195.26(84)^{* * *}$ & & .95 & .94 & .10 \\
\hline 1a) 3-factor model 1 (personal with national nostalgia) & $267.35(87)^{* * *}$ & $72.09^{* * *}$ & .92 & .90 & .09 \\
\hline 1b) 3-factor model 2 (national nostalgia with identification) & $642.65(87)^{* * *}$ & $447.39^{* * *}$ & .76 & .70 & .18 \\
\hline 1c) 3-factor model 3 (national nostalgia with prejudice) & $718.88(87)^{* * *}$ & $523.62^{* * *}$ & .72 & .66 & .19 \\
\hline 1d) 3-factor model 3 (identification with prejudice) & $848.42(87)^{* * *}$ & $653.16^{* * *}$ & .66 & .59 & .21 \\
\hline 1e) 1 -factor model & $1546.04(90)^{* * *}$ & $1350.78^{* * *}$ & .36 & .25 & .29 \\
\hline \multicolumn{6}{|l|}{ Study 2} \\
\hline 1) 6-factors & $779.73(237)^{* * *}$ & & .97 & .96 & .05 \\
\hline 2a) 5-factor model 1 (national nostalgia with identification) & $4164.39(242)^{* * *}$ & $3384.66^{* * *}$ & .78 & .74 & .13 \\
\hline 2b) 5 -factor model 2 (national nostalgia with ethnic national identity) & $2209.87(242)^{* * * *}$ & $1430.14^{* * *}$ & .89 & .87 & .09 \\
\hline 2c) 5 -factor model 3 (national nostalgia with PCC) & $4469.44(242)^{* * *}$ & $3689.71^{* * *}$ & .76 & .72 & .14 \\
\hline 2d) 5-factor model 4 (national nostalgia with uncertainty) & $3235.64(242)^{* * *}$ & $2455.91^{* * *}$ & .83 & .80 & .12 \\
\hline 2e) 5 -factor model 5 (ethnic national identity with prejudice) & $2131.24(242)^{* * *}$ & $1351.51^{* * *}$ & .89 & .88 & .09 \\
\hline 2f) 1-factor & $12646.79(252)^{* * *}$ & $11867.06^{* * *}$ & .29 & .22 & .23 \\
\hline
\end{tabular}

Note: $\mathrm{CFI}=$ comparative fit index, RMSEA = root mean square error of approximation, TLI = Tucker-Lewis coefficient.

*** $p<.001$.

Table 2

Bivariate correlations, means and standard deviations of the main constructs and covariates, Study 1.

\begin{tabular}{|c|c|c|c|c|c|c|}
\hline & $M$ & SD & 1 & 2 & 3 & 4 \\
\hline 1. National nostalgia & 2.57 & 1.05 & - & & & \\
\hline 2. Personal nostalgia & 2.03 & .76 & $.49^{* * *}$ & - & & \\
\hline 3. Out-group prejudice & 6.09 & 1.89 & $.34^{* * *}$ & $-.55^{* * *}$ & - & \\
\hline 4. National identification & 4.95 & 1.41 & $.33^{* * *}$ & $.20^{* *}$ & .08 & - \\
\hline \multicolumn{7}{|l|}{ Covariates } \\
\hline 5. Gender & - & - & $.17^{*}$ & -.02 & $.18^{*}$ & .08 \\
\hline 6. Age & 51.83 & 14.91 & $.20^{* *}$ & -.08 & $.26^{* * *}$ & $.14^{* * *}$ \\
\hline 7. Education & 6.65 & 1.38 & $-.32^{* * *}$ & $-.25^{* * *}$ & $-.21^{* * *}$ & $-.28^{* * *}$ \\
\hline 8. Political orientation & 2.85 & 1.19 & $.34^{* * *}$ & $.24^{* * *}$ & $.36^{* * *}$ & $.24^{* * *}$ \\
\hline
\end{tabular}

Netherlands: Turks, Moroccans, Surinamese and Antilleans. These items were recoded so that a higher score stands for stronger prejudice. A single scale for out-group prejudice $(\alpha=.87)$ was created.

2.1.2.3. National identification. National identification was measured with four items ( $\alpha=.93)$, using a scale ranging from 1 (strongly disagree) to 7 (strongly agree). Two sample items were: "I identify strongly with the Netherlands" and "I feel really Dutch".

\subsection{Results}

\subsubsection{Confirmatory factor analyses}

Confirmatory factor analyses (CFA) were performed, using AMOS software (version 21.0), to determine whether the items assessing personal nostalgia, national nostalgia, national identification, and out-group prejudice composed different factors. The fit of a four-factor model was compared with various three-factor models, and with the fit of a one-factor model. Items were only allowed to load on the factor they were expected to indicate. The results of the analyses are shown in Table 1 . The proposed four factor structure had a good fit to the data. The $z$-statistics obtained for all the factor loadings were statistically significant $\left(p_{s}<.001\right)$ and the standardized factor loadings were all above .60. Chi-square difference tests indicated that the proposed four-factor structure fit the data better than any of the alternative models, which indicates that personal nostalgia, national nostalgia, national identification, and out-group prejudice are separate constructs (see Table 2 for descriptive findings and bivariate correlations between the core constructs and covariates).

\subsubsection{Structural equation modeling}

Structural equation modeling in AMOS 21.0 was subsequently performed, using latent variables for national nostalgia, personal nostalgia, national identification and out-group prejudice. This provides more reliable results than path analyses using only manifest variables (Kline, 2005). The control variables (i.e., gender, age, education, and political orientation) were included as predictors of national identification and out-group prejudice in the model. To test our predictions the model in Fig. 1 was specified, which shows the standardized paths, correlations between latent variables, explained variance $\left(R^{2}\right)$, 


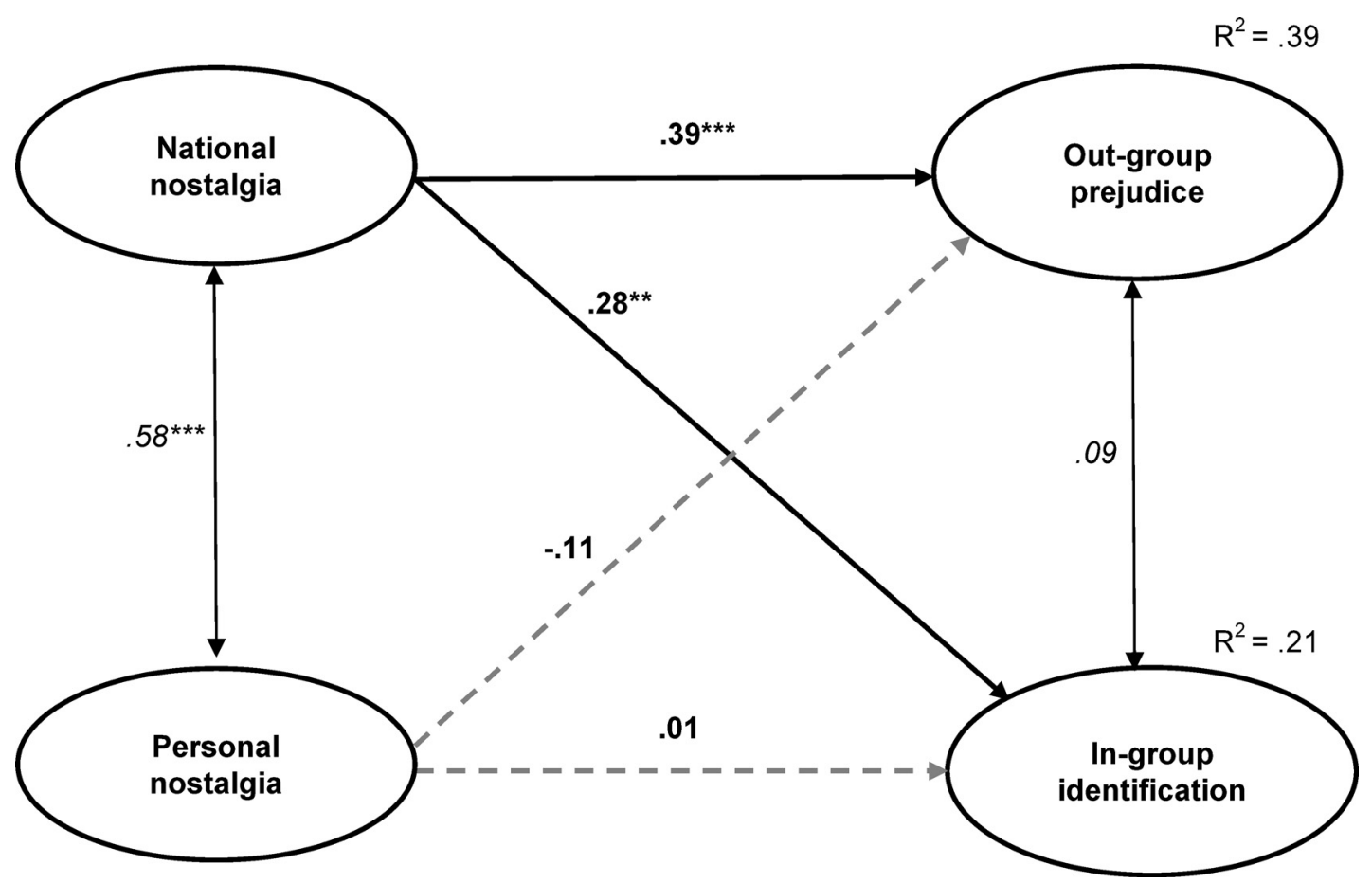

Fig. 1. Structural equation model (Study 1): Influence of national and personal nostalgia on out-group prejudice and in-group identification, (including age, gender, education, and political orientation as controls).

Note: Path coefficients are standardized estimates (marked in boldface), and the path coefficient in parenthesis reflects the total effect. Non-significant paths are shown with broken grey arrows. Correlation coefficients are displayed in Italics. ${ }^{* *} p<.01,{ }^{* * *} p<.001$. To simplify, indicators of latent variables and control variables are not shown. Model fit: $\chi^{2}(128)=211.89, p<.001 ; \mathrm{CFI}=.96, \mathrm{TLI}=.94, \mathrm{RMSEA}=.06$.

and model fit statistics. ${ }^{1}$ These analyses revealed that national nostalgia significantly and positively predicted out-group prejudice and in-group identification. Personal nostalgia was not significantly related to any of the dependent measures.

\section{Study 2}

The results of Study 1 demonstrated that national nostalgia is related to more in-group identification as well as to more prejudice towards immigrant out-groups. In addition, Study 1 replicated earlier findings on group-based nostalgia among a broader adult population (i.e., Smeekes et al., 2014, Study 1; Wildschut et al., 2014, Studies 1 and 2), by showing that feelings of national nostalgia are empirically distinct from feelings of personal nostalgia and that only the former is a relevant predictor of in-group identification and out-group prejudice. Furthermore, these relationships remained significant when controlling for several background characteristics of the respondents (i.e., age, gender, education and political orientation).

Study 2 aimed to replicate and build on the findings of Study 1 in various ways. First, it was examined whether the representation of ethnic national identity functions as a mediator between national nostalgia on the one hand and in-group identification and out-group prejudice on the other hand. It was predicted that national nostalgia would be related to more in-group identification and more out-group prejudice, via a stronger sense of ethnic national identity. This hypothesis was examined among a representative sample of the native Dutch population.

Second, Study 2 used a measure of national nostalgia that was different from the one used in Study 1. In Study 1, national nostalgia was assessed by asking people to indicate to what extent they longed for several specific aspects from their national in-group past. In Study 2, national nostalgia was measured by asking people to indicate to what extent they experience a more general sentimental longing for the country of the past. In this way, it can be tested whether a different and more general measure of the same construct produces similar results.

\footnotetext{
${ }^{1}$ Based on the modification indices, we allowed a correlation between the error terms of the two feeling thermometer items towards Surinamese and Antilleans. This was necessary in order to reach acceptable model fit. It is not surprising that these error terms show a correlation as Surinamese and Antilleans are often perceived as similar minority groups by the native Dutch majority. The reason is that Suriname and the Netherlands Antilles are former Dutch colonies in the Caribbean area, of which many immigrants arrived in the Netherlands since the 1970s. Because of this colonial history, both groups already had some affinity with Dutch culture and good language proficiency before arrival in the Netherlands. This is in contrast with the two other biggest non-western migrant groups in the Netherlands, Turks and Moroccans, who are not part of former colonies and show bigger gaps with the native majority as well as other minority groups in terms of socio-economic status and cultural beliefs (Gijsberts, Huijnk, \& Dagevos, 2012 for an overview of the Dutch immigration history, see Vermeulen \& Penninx, 2000).
} 
Third, Study 2 aimed to provide further evidence for the empirical distinctiveness and unique predictive power of national nostalgia. That is, the aim was not only to show that national nostalgia can be distinguished from both mediators and dependent variables, but also that it is empirically distinct from the potentially related constructs of uncertainty and perceived collective continuity. These constructs have also been shown to predict out-group attitudes and in-group identification in previous studies (see Hogg, 2007; Smeekes \& Verkuyten, 2013, 2014). It was subsequently examined whether the hypothesized relationships exist when controlling for these related constructs.

\subsection{Method}

\subsubsection{Participants}

Participants for this study $(N=928)$ were recruited in December 2011 from a nationally representative sample of the native Dutch population of 18 years and older. ${ }^{2}$ The sample was representative in terms of age, gender, education, household size and region of residence. Participants were recruited online through a Dutch consultancy company (TNS NIPO), which maintains a database of people who can be approached for surveys. The participants completed the questionnaire online. The age of the participants ranged from 18 to 88 years $(M=49.84, \mathrm{SD}=17.15)$, and $47.7 \%$ was female.

\subsubsection{Measures}

Out-group prejudice was measured with the same four items as in Study $1(\alpha=.84)$, which were again recoded so that a higher score corresponds to stronger out-group prejudice. Measures of national identification $(\alpha=.94)$, as well as the covariates, were identical to Study 1.

3.1.2.1. National nostalgia. Four items taken from previous research (Smeekes et al., 2014) were used to assess to what extent participants experienced national nostalgia $(\alpha=.91)$ : "How often do you experience nostalgia when you think about the Netherlands of the past?", "How often do you long for the good old days of the country?", "How often do you long for the Netherlands of the past?", "How often do you feel nostalgic when you hear Dutch songs from the past?" Items were rated on a scale ranging from 1 (very rarely) to 5 (very frequently).

3.1.2.2. Ethnic national identity. The extent to which participants perceived that national group membership is based on shared roots and common descent was measured with the following two items: "A real Dutch person is someone who has Dutch origins", and "A real Dutch person has Dutch ancestors" $(r=.88, p<.001)$. Items were rated on a scale ranging from 1 (strongly disagree) to 7 (strongly agree). These two items were combined into one scale.

3.1.2.3. Perceived cultural continuity. The 5-item scale (7-point scales) developed by Sani et al. (2007) was used to measure perceived cultural continuity $(\alpha=.92)$. Two sample items were: "Shared Dutch values and beliefs of Dutch people have endurance across times", and "Dutch people have passed on their traditions across different generations".

3.1.2.4. Uncertainty. Uncertainty was assessed with 5-items (7-point scales) from Greco and Roger's (2001) Emotional Uncertainty Scale $(\alpha=.93)$. Two sample items were: "I feel anxious when things are changing", and "I get worried when a situation is uncertain".

3.1.2.5. Covariates. I controlled for standard demographic characteristics of gender (coded as $1=$ male, $0=$ female), age and education (a scale ranging from 1 (primary education) to 8 (university degree)), and also for political orientation with the political self-placement scale (Jost, 2006), ranging from 1 (left) to 5 (right).

\subsection{Results}

\subsubsection{Confirmatory factor analyses}

Confirmatory factor analyses (CFA), in AMOS 21.0, was performed in order to determine whether the items assessing national nostalgia, national identification, ethnic national identity, out-group prejudice, perceived cultural continuity, and uncertainty composed different factors. I compared the fit of a six-factor model with various five-factor models, and with the fit of a one-factor model. Items were only allowed to load on the factor they were expected to indicate and no items were allowed to correlate. The results of the analyses are shown at the bottom of Table 1 . The proposed six-factor structure had a good fit to the data. The $z$-statistics obtained for all the factor loadings were statistically significant $\left(p_{\mathrm{s}}<.001\right)$ and the standardized factor loadings were all above .67. Chi-square difference tests indicated that the proposed five-factor structure fit the data better than any of the alternative models, which indicates that national nostalgia, national identification, 
Table 3

Bivariate correlations, means and standard deviations of the main constructs and covariates, Study 2.

\begin{tabular}{|c|c|c|c|c|c|c|c|c|}
\hline & $M$ & SD & 1 & 2 & 3 & 4 & 5 & 6 \\
\hline 1. National nostalgia & 2.71 & .96 & - & & & & & \\
\hline 2. Ethnic national identity & 4.54 & 1.70 & $.37^{* * *}$ & - & & & & \\
\hline 3. Out-group prejudice & 5.93 & 1.64 & $.30^{* * * *}$ & $.37^{* * *}$ & - & & & \\
\hline 4. National identification & 5.40 & 1.13 & $.24^{* * *}$ & $.33^{* * *}$ & $.07^{*}$ & - & & \\
\hline 5. Perceived cultural continuity & 5.04 & 1.03 & .01 & $.10^{* *}$ & $-.10^{* *}$ & $.45^{* * *}$ & - & \\
\hline 6. Uncertainty & 3.52 & 1.25 & $.41^{* * *}$ & $.32^{* * *}$ & $.31^{* * *}$ & $.16^{* * *}$ & .04 & - \\
\hline \multicolumn{9}{|l|}{ Covariates } \\
\hline 7. Gender & - & - & .00 & .00 & $.08^{*}$ & -.02 & $-.07^{*}$ & -.06 \\
\hline 8. Age & 49.84 & 17.15 & $.19^{* * *}$ & $.08^{*}$ & -.02 & $.16^{* * *}$ & .02 & -.02 \\
\hline 9. Education & 5.23 & 1.76 & $-.27^{* * *}$ & $-.27^{* * *}$ & $-.20^{* * *}$ & $-.14^{* * *}$ & -.04 & $-.20^{* * *}$ \\
\hline 10. Political orientation & 2.98 & 1.08 & $.13^{* * *}$ & $.22^{* * *}$ & $.28^{* * *}$ & $.10^{* *}$ & -.03 & $.12^{* * *}$ \\
\hline
\end{tabular}

${ }^{*} p<.05$.

** $p<.01$.

*** $p<.001$.

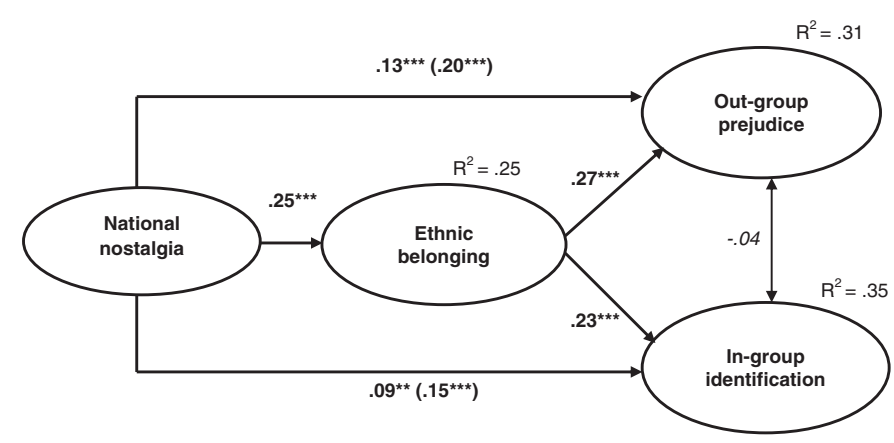

Fig. 2. Structural equation model (Study 2): Influence of national nostalgia on out-group prejudice and in-group identification, via ethnic national identity (including age, gender, education, political orientation, perceived cultural continuity, and uncertainty as controls).

Note: Pathcoefficients are standardized estimates (marked in boldface), and the path coefficient in parenthesis reflects the total effect. Correlation coefficients are displayed in Italics. ${ }^{* *} p<.01,{ }^{* * *} p<.001$. To simplify, indicators of latent variables and control variables are not shown. Model fit: $\chi^{2}(309)=1024.79$, $p<.001 ; \mathrm{CFI}=.96, \mathrm{TLI}=.95, \mathrm{RMSEA}=.05$.

perceived cultural continuity, common belonging and out-group prejudice are separate constructs (see Table 3 for descriptive findings and bivariate correlations between the core constructs and covariates).

\subsubsection{Structural equation modeling}

Structural equation modeling (with AMOS 21.0) was again conducted, using latent variables for national nostalgia, ethnic national identity, national identification and out-group prejudice. In order to control for any potential confounding influences on our hypothesized relations, I included gender, age, education, political orientation, perceived cultural continuity and uncertainty (both latent variables) as predictors of ethnic national identity, national identification and out-group prejudice in the model. To test the predictions the model in Fig. 2 was specified, which shows the standardized paths, correlations between latent variables, explained variance $\left(R^{2}\right)$, and model fit statistics. These analyses revealed that national nostalgia positively predicted ethnic national identity, national identification and out-group prejudice. In addition, ethnic national identity was found to be a positive predictor of both national identification and out-group prejudice.

I subsequently tested the indirect effects of national nostalgia on out-group prejudice and national identification, via ethnic national identity, using bootstrapping procedures (1000 samples) and controlling for the covariates. This was examined using 95\% bias-corrected confidence intervals. The indirect effect of national nostalgia on out-group prejudice was positive and significant, $\beta=.07, p=.002$ (lower $\mathrm{CI}=.045$, upper $\mathrm{CI}=.072$ ). Furthermore, the indirect effect of national nostalgia on national identification was also positive and significant, $\beta=.06, p=.002$ (lower $\mathrm{CI}=.038$, upper $\mathrm{CI}=.083$ ). The main effects of national nostalgia on out-group prejudice and national identification remained significant when the mediator was included in the model (see Fig. 2), indicating partial mediation.

\footnotetext{
2 This dataset as well as subsets of this dataset have been used in other studies (e.g., Martinovic \& Verkuyten, 2013; Smeekes et al., 2014; Verkuyten, Martinovic, \& Smeekes, 2014). Some of these studies have used the same measures as Study 2. However, none of these previous studies have examined how national nostalgia is related to ethnic national identity, out-group prejudice, and national identification.
} 


\section{Study 3}

The findings of Study 2 replicated those of Study 1 among a nationally representative sample, and additionally provided support for the prediction that national nostalgia is positively related to in-group identification and out-group prejudice, via the endorsement of ethnic national identity. Importantly, these relationships were established while controlling for background characteristics of the respondents as well as for potential confounding variables (i.e., perceived cultural continuity and uncertainty). The findings of Study 2 are in line with previous theorizing and empirical research suggesting that nostalgia serves to repair a sense of identity continuity in a context of social change and disruption (Boym, 2001; Davis, 1979; Hewison, 1987; Milligan, 2003). That is, by repairing the longing for the past with a sense of belonging based on common descent, national nostalgia is related to more embracement of the national in-group and rejection of relevant out-groups as a means to maintain identity continuity.

Another study was conducted to replicate these findings, but also to extend them by including in-group protection as an additional dependent measure. Previous research has shown that there are multiple ways in which in-group members can attempt to restore the continuity of their group identity. Specifically, studies have found that when the continuity of the in-group is at stake people not only try to minimize the presence of out-groups (e.g., Jetten \& Wohl, 2012), but also try to maximize the protection of in-group identity (Smeekes \& Verkuyten, 2013; Wohl, Branscombe, \& Reysen, 2010). These studies have shown that when threats to the continued existence of the in-group were salient this increased group member's desire to engage in in-group strengthening behaviors, such as promoting and protecting the in-group way of life. The reason is that a feeling of collective continuity is not only derived from a shared past, but also from the belief that this collective continues to be in the future (Condor, 1996). In longing for their lost national home of the past, group members not only become aware of their shared past experiences but also of the importance of their original culture and traditions as a basis for preserving their moral community. It is therefore likely that these nostalgic feelings make natives want to restore their original identity in the present and to protect their ways of life in the future.

The idea that group-based nostalgia leads to tendencies to protect the in-group in the future is supported by recent findings from an experiment among college students (Wildschut et al., 2014, Study 2), showing that that when making nostalgia for a shared event in their student life salient this resulted in intentions to support their fellow students in a publicity campaign for the university in the future. Thus, Study 3 examined whether, next to out-group prejudice and in-group identification, national nostalgia would be related to tendencies to protect the heritage of the national in-group. Following theoretical and qualitative work on group-based nostalgia (Boym, 2001; Davis, 1979; Milligan, 2003) it was predicted that national nostalgia is related to stronger tendencies to protect the national in-group, via stronger endorsement of ethnic national identity. The reason is that one way in which the national culture and identity of the past can be restored and protected in the future is by drawing sharp and fixed boundaries between those who were part of this shared national past and those who were not.

\subsection{Method}

\subsubsection{Participants}

Participants for this study were part of a new data collection among a nationally representative sample of the native Dutch population of 18 years and older $(N=802)$, again using the database maintained by TNS-NIPO. ${ }^{3}$ People who participated in Study 1 were not invited to participate in Study 2, thereby yielding two independent samples. The participants were between 18 and 87 years old $(M=50.71, S D=17.19)$, and $50 \%$ was female. They completed an online version of the questionnaire. The sample was again representative in terms of age, gender, education, household size and region of residence. The age of the participants ranged from 18 to 87 years $(M=50.68, S D=17.17)$, and $50 \%$ was female.

\subsubsection{Measures}

The measures for out-group prejudice ( $\alpha=.81$ ), national identification $(\alpha=.93)$, ethnic national identity $(r=.86)$, as well as the background characteristics (i.e., age, gender, education, and political orientation), were identical to Study 2. National nostalgia was measured with a single item: "I long for the Netherlands of the past". The measure for in-group protection was taken from Smeekes and Verkuyten (2013) and was assessed using the following three items $(\alpha=.88)$ : "It is important to protect original Dutch norms and values", "It is important to preserve the original Dutch culture and traditions", and "We should protect the Dutch way of life against groups and developments that undermine this identity".

\subsection{Results}

\subsubsection{Confirmatory factor analyses}

A confirmatory factor analysis in AMOS 21.0 verified that the proposed 4-factor structure-distinguishing between ethnic national identity, national identification, in-group protection, and out-group prejudice adequately represented the data,

\footnotetext{
3 This dataset has been used in other studies (e.g., Hindriks, Verkuyten, \& Coenders, 2014; Martinovic \& Verkuyten, 2013; Smeekes \& Verkuyten, 2013; Verkuyten et al., 2014). Some of these studies have used the same measures of out-group prejudice, national identification, in-group protection, and ethnic national identity as Study 3. However, none of these previous studies have examined how national nostalgia is related to these concepts.
} 
Table 4

Bivariate correlations, means and standard deviations of the main constructs and covariates, Study 3 .

\begin{tabular}{|c|c|c|c|c|c|c|c|}
\hline & $M$ & SD & 1 & 2 & 3 & 4 & 5 \\
\hline 1. National nostalgia & 4.09 & 1.50 & - & & & & \\
\hline 2. Ethnic national identity & 4.34 & 1.74 & $.19^{* * *}$ & - & & & \\
\hline 3. Out-group prejudice & 6.54 & 1.72 & $.20^{* * *}$ & $.39^{* * *}$ & - & & \\
\hline 4. National identification & 5.53 & 1.02 & $.20^{* * *}$ & $.35^{* * *}$ & $.21^{* * * *}$ & - & \\
\hline 5. In-group protection & 5.64 & 1.02 & $.32^{* * *}$ & $.43^{* * *}$ & $.38^{* * *}$ & $.59^{* * *}$ & - \\
\hline \multicolumn{8}{|l|}{ Covariates } \\
\hline 6. Gender & - & - & -.04 & .05 & $.11^{* *}$ & $.09^{*}$ & $.10^{* *}$ \\
\hline 7. Age & 50.68 & 17.17 & .05 & $.09^{*}$ & -.06 & $.20^{* * *}$ & $.15^{* * *}$ \\
\hline 8. Education & 5.07 & 1.72 & $-.18^{* * *}$ & $-.22^{* * *}$ & $-.19^{* * *}$ & $-.21^{* * *}$ & $-.28^{* * *}$ \\
\hline 9. Political orientation & 2.92 & 1.05 & $.10^{* *}$ & $.28^{* * *}$ & $.26^{* * *}$ & $.22^{* * *}$ & $.29^{* * *}$ \\
\hline
\end{tabular}

${ }^{*} p<.05$.

** $p<.01$.

*** $p<.001$.

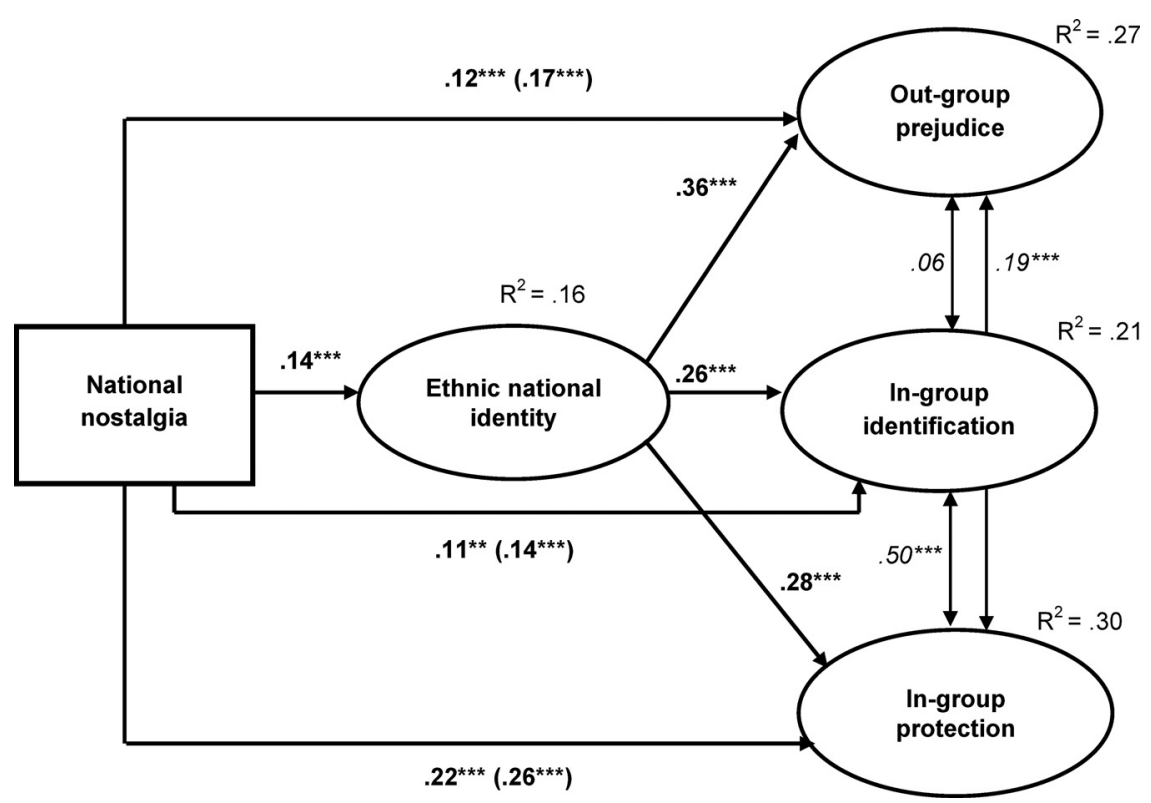

Fig. 3. Structural equation model (Study 3): Influence of national nostalgia onin-group identification, in-group protection and out-group prejudice, via ethnic national identity(includingage, gender, education, and political orientation as controls).

Note: Pathcoefficients are standardized estimates (marked in boldface), and the path coefficient in parenthesis reflects the total effect. Correlation coefficients are displayed in Italics. ${ }^{* *} p<.01,{ }^{* * *} p<.001$. To simplify, indicators of latent variables and control variables are not shown. Model fit: $\chi^{2}(104)=496.09$, $p<.001 ; \mathrm{CFI}=.95, \mathrm{TLI}=.93, \mathrm{RMSEA}=.07$.

$\chi^{2}(59)=376.09, p<.001, \mathrm{CFI}=.96, \mathrm{TLI}=.94, \mathrm{RMSEA}=.08$. This model had a better fit than a model that combined the items of out-group prejudice with those of in-group protection, $\chi^{2}(62)=1248.30, p<.001, \Delta \chi^{2}=872.21, \Delta \mathrm{df}=3, p<.001$, and also than a model that combined the items of national identification with those of in-group protection, $\chi^{2}(62)=1419.52, p<.001$, $\Delta \chi^{2}=1043.43, \Delta \mathrm{df}=3, p<.001$. Moreover, the 3-factor model also fit the data better than a model that combined the items of ethnic national identity with those of in-group protection, $\chi^{2}(62)=1389.96, p<.001, \Delta \chi^{2}=1013.87, \Delta \mathrm{df}=3, p<.001$. This indicates that these are all separate constructs (see Table 4 for descriptive findings and bivariate correlations between the core constructs and covariates).

\subsubsection{Structural equation modeling}

Structural equation modeling was again conducted (with AMOS 21.0) using latent variables for ethnic national identity, national identification, in-group protection and out-group prejudice. National nostalgia was included as a manifest predictor. Gender, age, education, and political orientation, were again included as controls in the model. To test our predictions the model in Fig. 3 was specified, which shows the standardized paths, correlations between latent variables, explained variance $\left(R^{2}\right)$, and model fit statistics. These analyses revealed that national nostalgia positively predicted ethnic national identity, in-group identification and in-group protection and out-group prejudice. In addition, ethnic national identity was found to be a positive predictor of both in-group protection and out-group prejudice. 
Subsequently, the indirect effects of national nostalgia on, in-group protection and out-group prejudice, via ethnic national identity, were tested. This was done using bootstrapping procedures (1000 samples; $95 \%$ bias-corrected confidence intervals) and while controlling for the covariates. The indirect effect of national nostalgia on out-group prejudice was positive and significant, $\beta=.05, p=.001$ (lower $\mathrm{CI}=.025$, upper $\mathrm{CI}=.083$ ), and so were the indirect effects on in-group protection, $\beta=.04, p=.001$ (lower $\mathrm{CI}=.018$, upper $\mathrm{CI}=.065$ ), and in-group identification $\beta=.04, p=.001($ lower $\mathrm{CI}=.017$, upper $\mathrm{CI}=.063)$. The main effects of national nostalgia on out-group prejudice, in-group identification and in-group protection remained significant when the mediator was included in the model (see Fig. 3), indicating partial mediation.

\section{General discussion}

The present research provides evidence that group-based nostalgia bears positive and negative relations to group dynamics at the same time. Although there have been recent studies showing that group-based nostalgia predicts positive orientations towards the in-group (Wildschut et al., 2014) and negative orientations towards relevant out-groups (Smeekes et al., 2014), no research has examined group-based nostalgia in relation to in-group and out-group orientations simultaneously.

The current research focused on group-based nostalgia for the nation (i.e., national nostalgia) and predicted that it is likely to have positive consequences for the in-group and negative consequences for the evaluations of out-groups, because it fosters an exclusionary and essentialist representation of the in-group. Combining propositions from SCT (Turner et al., 1987) with literature on moral communities (Haidt, 2007, p. 1000; see also Opotow et al., 2010) and essentialism (e.g., Haslam et al., 2006; Haslam et al., 2000), the theoretical reasoning was that national nostalgia is likely to activate an essentialist national in-group prototype that reflects the shared set of moral norms and values of the original national community, and which clearly marks group boundaries between first comers and newcomers in order to ensure a sense of identity continuity. An ethnic understanding of national identity was proposed to reflect such a national in-group prototype. This prediction was tested among native majority members in the Netherlands. Specifically, it was examined how their feelings of national nostalgia affect their levels of national in-group identification (Studies 1-3), the tendency to protect the national in-group (Study 3), and prejudice towards immigrant out-groups (Studies 1-3). In addition, in Studies 2 and 3 it was examined whether these effects are mediated by an ethnic understanding of national identity.

The findings of Study 1 provided support for the prediction that national nostalgia was positively related to in-group identification and out-group prejudice at the same time. Study 2 replicated this finding among a nationally representative sample of the native Dutch population, and furthermore provided evidence for the mediational role of ethnic national identity. Study 3 was also conducted among a nationally representative sample and showed that, next to out-group prejudice and national identification, national nostalgia was related to stronger tendencies to protect the national in-group, via a stronger sense of ethnic national identity. Importantly, throughout the studies, it was demonstrated that national nostalgia was empirically distinct from ethnic national identity and the two dependent variables, as well as from the potentially confounding constructs, such as personal nostalgia (Study 1), perceived cultural continuity, and uncertainty (Study 2). It was furthermore observed that the hypothesized relationships remained significant when controlling for these confounding variables as well as for general background characteristics of the respondents. These findings not only indicate that national nostalgia is a distinct and relevant psychological construct, but also that it has unique predictive power in group processes.

To my knowledge, this research provides the first demonstration of the differential effects of group-based nostalgia on intragroup and intergroup dynamics simultaneously. This is an interesting finding, as social psychologists have generally emphasized nostalgia as a positive emotion with beneficial consequences for individual well-being, intragroup and intergroup dynamics (Gebauer \& Sedikides, 2010; Turner et al., 2012, 2013; Wildschut et al., 2006, 2014). Moreover, most social psychological research considered nostalgia as an individual-level emotion with individual level outcomes, and there have been few studies examining nostalgia at the collective level in relation to group dynamics (yet see Smeekes et al., 2014; Wildschut et al., 2014). By showing that national nostalgia simultaneously positively affects the in-group and negatively affects evaluations of out-groups this research constitutes a step forward in understanding the dynamic role of group-based nostalgia in relation to group processes.

Another advancement of the present research is the introduction of ethnic national identity as a mediator between national nostalgia on the one hand and in-group identification, in-group protection, and immigrant out-group prejudice on the other. Although previous studies have shown that ethnic national identity predicts stronger levels of national ingroup identification and immigrant out-group prejudice (e.g., Duriez et al., 2013; Pehrson et al., 2009), the concept has so far not been linked to group-based nostalgia in the social psychological literature. The finding that national nostalgia is linked to positive outcomes for the in-group and negative evaluations of out-groups through the endorsement of ethnic national identity is in line with theoretical work and qualitative work on group-based nostalgia (Boym, 2001; Davis, 1979; Milligan, 2003). This work suggests that group-based nostalgia is likely to result in renewed exclusionary identity categories based on shared past experiences and values, in order to repair a sense of identity continuity. Taken together, these findings indicate that social categorization in terms of old-timers and newcomers together with ascribing essences to the old-timer category could be a general mechanism explaining the differential effects of group-based nostalgia on in-group and out-group orientations. This result represents a theoretical advancement over previous social psychological research on group-based nostalgia. 


\section{Limitations and directions for future research}

Despite the novel contributions of this research there are also limitations that provide directions for prospective studies. The first limitation is that the studies presented in this paper were based on cross-sectional data which does not allow for causal interpretations. Yet, previous experimental research has provided evidence for the positive causal influence of groupbased nostalgia on in-group identification and in-group support (Wildschut et al., 2014) and on negative intergroup attitudes (Smeekes et al., 2014). Studies have also demonstrated the positive causal effect of ethnic national identity on national identification and negative out-group attitudes (Duriez et al., 2013; Meeus, Duriez, Vanbeselaere, \& Boon, 2010; Wakefield et al., 2011). Moreover, the proposed causal relationships are in line with qualitative and theoretical work on group-based nostalgia (Boym, 2001; Davis, 1979; Duyvendak, 2011; Milligan, 2003). However, it is also possible that national nostalgia itself is a consequence of group dynamics. It has been shown that personal nostalgia is caused by threats to identity continuity (Sedikides, Wildschut, Routledge, \& Arndt, 2014) and similar mechanisms may operate at the collective level. This means that group-based nostalgia may itself be a psychological mechanism explaining how feelings of collective displacement and discontinuity translate into drawing group boundaries and negative intergroup relations and this deserves attention in future work.

In the theoretical section of this research it was argued that within group-based nostalgia there seems to lie a moral sentiment which idealizes the collective past as being one in which people still held "the right" norms and values and for which native majority members feel responsible in terms of ensuring its continuity. However, this moral component of national nostalgia was not explicitly measured in the different studies. Theoretical work by Turner (1987) has suggested that social discourses on nostalgia have four dimensions: a sense of historical loss and decline, the disappearance of genuine social relations, the loss of simplicity and the loss of personal wholeness and moral certainty. Whether group-based nostalgia has positive or negative consequences for group dynamics may thus depend on how it is defined and understood. That is, people can feel nostalgic for different periods or aspects of their shared past. Future work should try to capture such different dimensions and contents of group-based nostalgia and examine which ones are most relevant for understanding group dynamics.

Another point that warrants discussion is that the effect of national nostalgia on in-group and out-group orientations was only partially mediated by ethnic national identity in Studies 2 and 3, and that the indirect effect was rather small in both studies. This could indicate that, next to ethnic national identity, there are other processes that explain this effect. It has recently been shown that national nostalgia among native majority members increased their opposition to minority rights for Muslims, via a stronger belief in historical entitlements for their in-group, based on their status as primo-occupants of the country (Smeekes et al., 2014). It has been demonstrated that these so called "autochthony beliefs" are theoretically and empirically distinct from the concept of ethnic national identity, and uniquely predict prejudice towards immigrant out-groups (Martinovic \& Verkuyten, 2013). Autochthony focuses on a group's primo-occupancy of a territory with the related sense of ownership and group rights, whereas ethnic national identity refers to common ancestry and descent that can be independent of territorial borders. Yet, both concepts are essentialist in-group representations based on the social categorization between original inhabitants of the country versus newcomers. It is therefore likely that autochthony beliefs form another explanation for why national nostalgia is related to a positive in-group and negative out-group orientation at the same time, and this could be examined in prospective work.

The current research focused on national nostalgia among native majority members in the Netherlands. This means that it is unclear whether these findings can be generalized to other contexts and to other social identities. However, in various Western European countries there is a comparable nostalgic discourse in relation to feelings of displacement of native majority facing increasing cultural and religious diversification of their surroundings (see Duyvendak, 2011). Furthermore, qualitative research has found similar relationships between group-based nostalgia and group dynamics in organizational settings (Brown \& Humphreys, 2002; Milligan, 2003). Nevertheless, future studies could try to replicate and extend these findings in other countries, and focus on group-based nostalgia for a wider variety of social groups.

\section{Conclusion}

The key finding of the current research was that national nostalgia is related to positive outcomes for the national ingroup and negative outcomes for the evaluation of immigrant out-groups at the same time, via stronger endorsement of an exclusive and essentialist national in-group representation based on ethnicity. This result was obtained among broad and representative samples of the native Dutch population and it was furthermore confirmed that national nostalgia is an empirically distinct construct and a unique and relevant predictor of in-group and out-group orientations. The findings of this research have important implications for the understanding of group dynamics in culturally diverse settings, as they indicate that national nostalgia can sharpen group boundaries. This means that political and public discourses and media that invoke representations of a positively remembered national past that is lost run the risk of hampering positive intergroup relations. 


\section{References}

Asendorpf, J. B., Conner, M., De Fruyt, F., De Houwer, J., Denissen, J. J. A., Fiedler, K., et al. (2013). Recommendations for increasing replicability in psychology. European Journal of Personality, 27, 108-119. http://dx.doi.org/10.1002/per.1919

Batcho, K. I. (1998). Personal nostalgia, world view, memory, and emotionality. Perceptual and Motor Skills, 87, 411-432. http://dx.doi.org/10.2466/pms.1998.87.2.411

Batcho, K. I. (2013). Nostalgia: The bittersweet history of a psychological concept. History of Psychology, 13, 165-176. http://dx.doi.org/10.1037/a0032427

Best, J., \& Nelson, E. E. (1985). Nostalgia and discontinuity: A test of the Davis hypothesis. Sociology and Social Research, 69, $221-233$.

Boym, S. (2001). The future of nostalgia. New York: Basic Books.

Branscombe, N. R., \& Doosje, B. (2004). Collective guilt: International perspectives. Cambridge: Cambridge University Press

Brown, A. D., \& Humphreys, M. (2002). Nostalgia and the narrativization of identity: A Turkish case study. British Journal of Management, 13, 141-159. http://dx.doi.org/10.1111/1467 8551.00228

Condor, S. (1996). Social identity and time. In W. P. Robinson (Ed.), Social groups and identities: Developing the legacy of Henri Tajfel (pp. 285-315). Oxford, UK: Butterworth Heinemann.

Davis, F. (1979). Yearning for yesterday: A sociology of nostalgia. New York: The Free Press.

Duriez, B., Reijerse, A., Luyckx, K., Vanbeselaere, N., \& Meeus, J. (2013). Which national group will I identify myself with? The role of preferred and perceived identity representations. Nations and Naitonalism, 19, 456-474. http://dx.doi.org/10.1111/nana.12004

Duyvendak, J. (2011). The politics of home: Belonging and nostalgia in Western Europe and the United States. Ballingstoke, UK: Palgrave.

Frijda, N. H. (2007). The laws of emotion. Mahwah, NJ: Lawrence Erlbaum Associates.

Gebauer, J., \& Sedikides, C. (2010). Yearning for yesterday: Dwell on the past. It's good for you. Scientific American Mind, $23,30-35$. http://dx.doi.org/10.1038/scientificamericanmind0710-30

Gijsberts, M., Huijnk, W., \& Dagevos, J. (2012). Jaarrapport Integratie 2011 [Yearly report on Integration 2011]. Den Haag: The Netherlands Institute of Social Research.

Greco, V., \& Roger, D. (2001). Coping with uncertainty: The construction and validation of a new measure. Personality and Individual Differences, 31, 519-534. http://dx.doi.org/10.1016/S0191-8869(00)156-2

Haidt, J. (2007). The new synthesis in moral psychology. Science, 316, 998-1003. http://dx.doi.org/10.1126/science.1137651

Haslam, N., Bastian, B., Bain, P., \& Kashima, Y. (2006). Psychological essentialism, implicit theories, and intergroup relations. Group Processes and Intergroup Relations, 9, 63-76. http://dx.doi.org/10.1177/1368430206059861

Haslam, N., Rotschild, L., \& Ernst. (2000). Essentialist beliefs about social categories. British Journal of Social Psychology, 39, $113-127$. http://dx.doi.org/10.1348/014466600164363

Henrich, J., Heine, S. J., \& Norenzayan, A. (2010). The weirdest people in the world? Behavioral and Brain Sciences, 33, 61-135. http://dx.doi.org/10.1017/S0140525X0999152X

Henry, P. J. (2008). College sophomores in the laboratory redux: Influences of a narrow data base on social psychology's view of the nature of prejudice. Psychological Inquiry, 19, 49-71. http://dx.doi.org/10.1080/10478400802049936

Hepper, E. G., Ritchie, T. D., Sedikides, C., \& Wildschut, T. (2012). Odyssey's end: Lay conceptions of nostalgia reflect its original Homeric meaning. Emotion, 12, 102-119. http://dx.doi.org/10.1037/a0025167

Hewison, R. (1987). The heritage industry: Britain in a climate of decline. Sussex: Methuen.

Hindriks, P., Verkuyten, M., \& Coenders, M. (2014). Dimensions of social dominance orientation: The roles of legitimizing myths and national identification. European Journal of Personality, 28, 538-549. http://dx.doi.org/10.1002/per.1955

Hogg, M. A. (2007). Uncertainty-identity theory. Advances in Experimental Social Psychology, 39, 69-126. http://dx.doi.org/10.1016/S00652601(06)390028

Holbrook, M. B. (1993). Nostalgia and consumption preferences: Some emerging patterns of consumer tastes. Journal of Consumer Research, 20, 245-256. http://dx.doi.org/10.1086/209346

Iyer, A., \& Jetten, J. (2011). What's left behind: Identity continuity moderates the effect of nostalgia on well-being and life choices. Journal of Personality and Social Psychology, 101, 94-108. http://dx.doi.org/10.1037/a0022496

Jetten, J., Haslam, C., Pugliese, C., Tonks, J., \& Haslam, S. A. (2010). Declining autobiographical memory and the loss of identity: Effects on well-being. Journal of Clinical and Experimental Neuropsychology, 32, 408-416. http://dx.doi.org/10.1080/13803390903140603

Jetten, J., \& Wohl, M. J. A. (2012). The past as a determinant of the present: historical continuity, collective angst, and opposition to immigration. European Journal of Social Psychology, 42, 442-450. http://dx.doi.org/10.1002/ejsp.865

Jost, J. T. (2006). The end of the end of ideology. American Psychologist, 61, 651-670. http://dx.doi.org/10.1037/0003-066X.61.7.651

Kasinitz, P., \& Hillyard, D. (1995). The old timer's tale: The politics of nostalgia on the waterfront. Journal of Contemporary Ethnography, 24, 139-164. http://dx.doi.org/10.1177/089124195024002001

Kline, R. B. (2005). Principles and practice of structural equation modelling. New York: The Guilford Press.

Kunovich, R. (2009). The sources and consequences of national identification. American Sociological Review, 74, 573-593. http://dx.doi.org/10.1177/000312240907400404

Mackie, D. M., Devos, T., \& Smith, E. R. (2000). Intergroup emotions: Explaining offensive action tendencies in an intergroup context. Journal of Personality and Social Psychology, 79, 602-616. http://dx.doi.org/10.10371/0022-3514.79.4.602

Mackie, D. M., \& Smith, E. R. (1998). Intergroup relations: Insights from a theoretically integrative approach. Psychological Review, 105, 499-529. http://dx.doi.org/10.1037/0033-295X.105.3.499

Martinovic, B., \& Verkuyten, M. (2013). 'We were here first, so we determine the rules of the game': Autochthony and prejudice towards out-groups. European Journal of Social Psychology, 43, 637-647. http://dx.doi.org/10.1002/ejsp.1980

Meeus, J., Duriez, B., Vanbeselaere, N., \& Boon, F. (2010). The role of national identity representations in the relation between ingroup identification and outgroup derogation: Ethnic versus civic representations. British Journal of Social Psychology, 49, 305-320. http://dx.doi.org/10.1348/014466609X451455

Milligan, M. J. (2003). Displacement and identity discontinuity: The role of nostalgia in establishing new identity categories. Symbolic Interaction, 26, 381-403. http://dx.doi.org/10.1525/si.2003.26.3.381

Opotow, S., Gerson, J., \& Woodside, S. (2010). From moral exclusion to moral inclusion: Theory for teaching peace. Theory into Practise, 44, 303-318. http://dx.doi.org/10.1207/s15430421tipc4404_4

Pehrson, S., Brown, R., \& Zagefka, H. (2009). When does national identification lead to the rejection of immigrants? Cross-sectional and longitudinal evidence for the role of essentialist in-group definitions. British Journal of Social Psychology, http://dx.doi.org/10.1348/014466608X288827

Reicher, S., \& Hopkins, N. (2001). Self and nation. London. UK: Sage.

Sani, F. (Ed.). (2008). Self continuity: Individual and collective perspectives. In. New York: Psychology Press.

Sani, F., Bowe, M., Herrera, M., Manna, C., Cossa, T., Miao, X., et al. (2007). Perceived collective continuity: Seeing groups as entities that move through time. European Journal of Social Psychology, 37, 1118-1134. http://dx.doi.org/10.1002/ejsp.430

Sedikides, C., Wildschut, T., \& Baden, D. (2004). Nostalgia: Conceptual issues and existential functions. In J. Greenberg (Ed.), Handbook of experimental existential psychology (pp. 200-214). New York, NY: Guilford Press.

Sedikides, C., Wildschut, T., Routledge, C., \& Arndt, J. (2014). Nostalgia counteracts self-discontinuity and restores self-continuity. European Journal of Social Psychology, 38(45), 52-61. http://dx.doi.org/10.1002/ejsp.2073

Simons, D. J. (2014). The value of direct replication. Perspectives on Psychological Science, 9, 76-80. http://dx.doi.org/10.1177/1745691613514755 
Smeekes, A., \& Verkuyten, M. (2013). Collective self-continuity, group identification and in-group defense. Journal of Experimental Social Psychology, 49, 984-994. http://dx.doi.org/10.1177/1745691613514755

Smeekes, A., \& Verkuyten, M. (2014). Perceived group continuity, collective self-continuity, and in-group identification. Self and Identity, 13, 663-680. http://dx.doi.org/10.1080/15298868.2014.898685

Smeekes, A., Verkuyten, M., \& Martinovic, B. (2014). Longing for the country's good old days: National nostalgia, autochthony beliefs, and opposition to Muslim expressive rights. British Journal of Social Psychology (in press). http://dx.doi.org/10.1111/bjso.12097

Smith, A. (2001). Nationalism: Theory, ideology, history. Cambridge. MA: Polity Press.

Tajfel, H., \& Turner, J. C. (1979). An integrative theory of intergroup conflict. In W. G. Austin, \& S. Worchel (Eds.), The social psychology of intergroup relations (pp. 33-48). Monterey, CA: Brooks/Cole.

Terry, D. J., \& Hogg, M. A. (1996). Group norms and the attitude-behavior relationship: A role for group identification. Personality and Social Psychology Bulletin, 22, 776-793. http://dx.doi.org/10.1177/0146167296228002

Turner, B. S. (1987). A note on nostalgia. Theory, Culture and Society, 4, 147-156.

Turner, J. C., Hogg, M. A., Oakes, P. J., Reicher, S. D., \& Wetherell, M. S. (1987). Rediscovering the social group: A self-categorization theory. Oxford: Blackwell.

Turner, R. N., Wildschut, T., \& Sedikides, C. (2012). Dropping the weight stigma: Nostalgia improves attitudes toward persons who are overweight. Journal of Experimental Social Psychology, 48, 130-137. http://dx.doi.org/10.1016/j.jesp.2011.09.007

Turner, R. N., Wildschut, T., Sedikides, C., \& Gheorghiu, M. (2013). Combating the mental health stigma with nostalgia. European Journal of Social Psychology, 43, 413-422. http://dx.doi.org/10.1002/ejsp.1952

Verkuyten, M., Martinovic, B., \& Smeekes, A. (2014). The multicultural jigsaw puzzle: Category indispensability and acceptance of immigrants' cultural rights. Personality and Social Psychology Bulletin, 40, 1480-1493.

Vermeulen, H., \& Penninx, R. (2000). Immigrant integration. The Dutch case. Amsterdan: Het Spinhuis.

Wakefield, J. R. H., Hopkins, N., Cockburn, C., Shek, K. M., Muirhead, A., Reicher, S., \& Van Rijswijk, W. (2011). The impact of adopting ethnic or civic conceptions of national belonging for others' treatment. Personality and Social Psychology Bulletin, 37, 1599-1610. http://dx.doi.org/10.1177/0146167211416131

Wildschut, T., Bruder, M., Robertson, S., Tilburg, W. A. P., \& Sedikides, C. (2014). Collective nostalgia: A group-level emotion that confers unique benefits on the group. Journal of Personality and Social Psychology, 107, 844-863. http://dx.doi.org/10.1037/a0037760

Wildschut, T., Sedikides, C., Arndt, J., \& Routledge, C. (2006). Nostalgia: Content, triggers, functions. Journal of Personality and Social Psychology, 91, 975-993. http://dx.doi.org/10.1037/0022-3514.91.5.975

Wohl, M. J. A., Branscombe, N. R., \& Reysen, S. (2010). Perceiving your group's future to be in jeopardy: Extinction threat induces collective angst and the desire to strengthen the ingroup. Personality and Social Psychology Bulletin, 36, 898-910. http://dx.doi.org/10.1002/ejsp.865 